\title{
Pengaruh Metode Lightening The Learning Climate Terhadap Kreatifitas dan Kemampuan Berpikir Siswa
}

\author{
Amran Hapsan', Kristiawati² \\ 1. Pendidikan Matematika, PMIPA, STKIP Pembangunan Indonesia Makassar, Jln. \\ Inspeksi Kanal No. 10 Citraland, Makassar \\ 2. Universitas Muhammadiyah, Jln. Sultan Alauddin, Makassar \\ matematikamagic@gmail.com
}

Received: 6 November 2019; Accepted: 12 Desember 2019; Published: 29 Desember 2019

\begin{abstract}
Abstrak
Berpikir merupakan proses kognitif untuk memperoleh pengetahuan. Kemampuan berpikir manusia berdasarkan prosesnya dapat digolongkan menjadi dua jenis, yaitu kemampuan berpikir dasar dan kemampuan berpikir kompleks atau kemampuan berpikir tingkat tinggi. Proses kemampuan berpikir tingkat tinggi, diantaranya meliputi kemampuan berpikir kritis (tajam dalam menganalisis dan kreatif dan bersifat daya cipta). Kemampuan berpikir baik kemampuan berpikir kritis maupun berpikir kreatif merupakan hal penting dan sangat diperlukan peserta didik untuk menghadapi persoalan hidup di masa yang akan datang. Akan tetapi, kemampuan berpikir dan kreatifitas ini sering terabaikan dalam pembelajaran matematika di sekolah. Model pembelajaran yang diharapkan dapat meningkatkan kemampuan berpikir dan kreatifitas siswa adalah metode Lightening The Learning Climate. Dalam model pembelajaran ini siswa kebebasan untuk mengungkapkan ide dan pendapatnya pada saat proses pembelajaran berlangsung. Jenis penelitian ini adalah menggunakan metode design research. Penelitian ini dilakukan di Kabupaten Sidenreng Rappang Tahun Ajaran 2018/2019. Data yang diperoleh dalam penelitian ini adalah observasi untuk penentuan kelas yang dijadikan subyek penelitian, hasil uji kreatifitas dan kemampuan berpikir siswa serta penilaian hasil belajar siswa. Hasil penelitian yang dicapai setelah dianalisis menunjukkan bahwa Pembelajaran melalui penerapan metode Lightening the Learning Climate dapat meningkatkan kemampuan berpikir siswa dari 11,76\% menjadi 47,06\% untuk kategori tinggi; Terjadi juga peningkatan untuk kemampuan kreatifitas siswa dari 23,53\% menjadi 26,47\%. Dari penelitian di atas, maka dapat disimpulkan bahwa terjadi peningkatan kemampuan berpikir dan kreatifitas pada Sidenreng Rappang melalui penerapan metode Lightening the Learning Climate.
\end{abstract}

Kata kunci: kemampuan berpikir, kreatifitas, lightening the learning climate

\begin{abstract}
Thinking is a cognitive process for gaining knowledge. Human thinking ability based on the process can be classified into two types, namely basic thinking skills and complex thinking abilities or higher-level thinking skills. The process of high-level thinking skills, including the ability to think critically (sharp in analyzing and creative and creative). The ability to think both the ability to think critically and think creatively is important and is essential for students to deal with life's problems in the future. However, the ability to think and creativity is often overlooked in learning mathematics in school. The learning model that is expected to improve students' thinking abilities and creativity is the Lightening The Learning Climate method. In this learning model students have the freedom to express their ideas and opinions during the learning process. This type of research is to use the design research method. This research was conducted in Sidenreng Rappang academic year 2018/2019. The data obtained in this study are observations to determine the class that is used as the subject of research, the results of creativity tests and students' thinking abilities and assessment of student learning outcomes. The research results achieved after analysis showed that Learning through the application of the Lightening the Learning Climate method can improve students' thinking abilities from $11.76 \%$ to $47.06 \%$ for the high category; There has also been an increase in students' creative
\end{abstract}


abilities from $23.53 \%$ to $26.47 \%$. From the above research, it can be concluded that an increase in thinking ability and creativity of students in Sidenreng Rappang through the application of the Lightening the Learning Climate method.

Keywords: thinking ability, creativity, lightening the learning climate 


\section{PENDAHULUAN}

Berpikir merupakan proses kognitif untuk memperoleh pengetahuan. Menurut Liliasari (2011), kemampuan berpikir manusia berdasarkan prosesnya dapat digolongkan menjadi dua jenis, yaitu kemampuan berpikir dasar dan kemampuan berpikir kompleks atau kemampuan berpikir tingkat tinggi. Proses kemampuan berpikir tingkat tinggi, diantaranya meliputi kemampuan berpikir kritis (tajam dalam menganalisis dan kreatif dan bersifat daya cipta). Kemampuan berpikir baik kemampuan berpikir kritis maupun berpikir kreatif merupakan hal penting dan sangat diperlukan peserta didik untuk menghadapi persoalan hidup di masa yang akan datang. Berpikir kreatif di bidang pendidikan akan membantu siswa dalam memecahkan suatu masalah yang dihadapi dalam proses belajar, Yuliana (2013).

Berdasarkan data dari hasil observasi dan wawancara langsung yang dilakukan di MTsN 2 Sidenreng Rappang Semester Ganjil (1) Tahun Ajaran 2017/2018, diperoleh informasi bahwa hasil belajar matematika siswa kelas VIII $_{C}$ hanya berkisar antara $20-60$. Sedangkan nilai Kriteria Ketuntasan Minimal (KKM) yang sudah disepakati adalah 69. Dari hasil wawancara dan observasi ini juga diperoleh informasi bahwa siswa masih bingung menjawab pertanyaanpertanyaan, padahal soal yang diberikan termasuk pada soal konsep matematika dalam kehidupan sehari-hari. Kemampuan siswa yang rendah dalam menyelesaikan soal yang berkaitan dengan pemahaman konsep tentunya menjadi masalah dalam pembelajaraan matematika. Rendahnya hasil belajar matematika tersebut disebabkan karena kurangnya pemahaman konsep siswa terhadap materi yang terdapat pada mata pelajaraan matematika.

Hasil wawancara dengan beberapa orang siswa kelas VIII $_{C}$ MTsN 2 Sidenreng Rappang yang dilakukan saat jam istirahat, siswa merasa bahwa pendekatan pembelajaran matematika di sekolah tersebut yang sering digunakan sebagian besar guru kurang memberikan kesempatan kepada siswa untuk menyampaikan ide-ide yang ada padanya. Pembelajaran matematika didominasi oleh guru. Guru menjelaskan konsep matematika, memberikan contoh soal, mendemonstrasikan penyelesaian soal, memberikan rangkuman, dan memberikan soal latihan. Siswa diposisikan sebagai penerima apa yang disampaikan oleh guru, akibatnya siswa menjadi pasif dalam belajar matematika. Selain itu, ketika siswa disuruh membuat model soal matematika, kebanyakan dari mereka tidak bisa dan ketika diminta memberikan alasanya terhadap jawaban yang mereka peroleh, masih banyak siswa kebingungan, guru hanya memberikan soal dan meminta jawaban siswa mengerjakan latihan mengikuti pola yang telah dicontohkan oleh guru. Siswa lebih banyak pasif dan tidak terlibat aktif dalam membangun konsep tentang matematika yang dipelajarinya, bahkan jarang sekali siswa diminta gagasan ataupun idenya tentang konsep-konsep matematika tersebut.

Adapun cara yang ditempuh untuk mengatasi permasalahan-permasalahan di atas adalah dengan menggunakan inovasi dalam pembelajaran. Salah satu pendekatan pembelajaran yang dapat diterapkan pembelajaran matematika untuk mengembangkan kemampuan pemahaman konsep matematika siswa adalah menggunakan pendekatan post solution posing dimana pendekatan ini memberikan pengaruh positif pada siswa. Pembelajaran dengan pendekatan post solition posing adalah pembelajaran yang menekankan pada siswa untuk membentuk atau mengajukan soal berdasarkan informasi atau situasi yang diberikan. Informasi yang ada diolah dalam pikiran dan setelah dipahami maka peserta didik akan bisa mengajukan pertanyaan.

Penelitian yang dilakukan oleh penulis dengan judul "Pengaruh Metode Lightening The Learning Climate terhadap Kreatifitas dan Kemampuan Berpikir Siswa" diharapkan dapat bermanfaat bagi guru sebagai alternatif strategi mengajar yang diterapkan di sekolah untuk 
meningkatkan kreatifitas dan kemampuan berpikir siswa.

\section{METODE}

Penelitian ini menggunakan metode design research. Langkah proses penelitian design research seperti halnya pada proses perancangan pendidikan (educational design), yaitu analisis, perancangan, evaluasi dan revisi yang merupakan proses siklikal yang berakhir pada keseimbangan antara teori ideal dengan praktiknya.

Menurut Gravemeijer \& Cobb (2006) tahapan pelaksanaan design research adalah:

1) preparing for the experiment (persiapan penelitian)

2) design experiment (pelaksanaan desain eksperimen)

3) retrospective analysis (analisis data yang diperoleh dari tahap sebelumnya).

Penelitian ini dilaksanakan pada tahun ajaran baru 2018/2019 semester II di MTsN 2 Sidenreng Rappang. Populasi dalam penelitian ini adalah seluruh siswa kelas $\mathrm{VIII}_{\mathrm{C}}$ yang terdiri dari 34 siswa. Teknik penentuan sampel dilakukan dengan wawancara dengan salah seorang guru yang ada di sekolah tersebut dengan memperhatikan nilai semester ganjil kelas yang diajar oleh guru tersebut. Peneliti juga melakukan interview atau wawancara secara mendalam kepada informan dan responden yang dianggap mengetahui permasalahan. Teknik pengumpulan data dilakukan melalui: (1) Melakukan observasi untuk menentukan kelas yang akan dijadikan kelompok subyek penelitian serta menetukan kelas eksperimen yaitu yang akan diperlakuan uji kreatifitas dan kemampuan berpikir; (2) Melakukan treatment (perlakuan) kepada kelas yang dijadikan sebagai subyek penelitian dengan perlakuan kreatifitas dan kemampuan bepikir; (3) Mengambil data hasil uji kreatifitas dan kempuan berpikir siswa; dan (4) Menilai hasil belajar siswa yang di peroleh dari kedua perlakuan yaitu:uji kreatifitas dan kemampuan berpikir. Selanjutnya data yang telah di peroleh dianalisis dan siap untuk membuat laporan penelitian.

\section{HASIL DAN PEMBAHASAN}

Kemampuan berpikir merupakaan kegiatan penalaraan yang reflektif', kritis, dan kreatif yang beriorentsi pada suatu proses intelektual yang melibatkan pembentukan konsep, analisis, menilai informasi yang terkumpul atau dihasilkan melalui pengamatan, pengalaman, refleksi, komunikasi sebagai landasan kepada suatu keyakinan dan tindakan. Berpikir adalah suatu keaktifan pribadi manusia yang mengakibatkan penemuan yang terarah pada suatu tujuan. Ada tiga langkah proses berjalannya berpikir yaitu:

a. Pembentukan pengertian yaitu menganalisis ciri-ciri dari sejumlah objek yang sejenis, contohnya menganalisis manusia dari eropa

b. Pembentukan pendapat yaitu meletakan hubungan antara dua buah pengertian atau lebih

c. Pembentukan keputusan atau penarikan kesimpulan yaitu hasil perbuatan akal untuk membentuk pendapat baru berdasarkan pendapat-pendapat yang telah ada.

Berdasarkan hasil perhitungan data pretest diketahui bahwa siswa yang memiliki nilai tertinggi sebesar 100 dan nilai terendah adalah 33 sedangkan nilai rata-rata pre test sebesar 60,35 dengan nilai median sebesar 52,50 nilai modus sebesar 50, nilai varians sebesar 471,57 dan nilai simpangan baku sebesar 21,72. Selanjutnya untuk mempermudah pembaca atas data hasil test di atas langkah selanjutnya adalah pembuatan data statistik dan distribusi frekuensi untuk data-data yang telah dikelompokan adalah sebagai berikut: 
Tabel 1. Data Hasil Pretest kemampuan berpikir siswa

\begin{tabular}{cc}
\hline Skor & Nilai Pre test \\
\hline Mean & 60,35 \\
\hline Median & 52,50 \\
\hline Modus & 50,00
\end{tabular}

\begin{tabular}{cc}
\hline Varians & 471,57 \\
\hline Simpangan baku & 21,72 \\
\hline Nilai maksimum & 100 \\
\hline Nilai minimum & 33 \\
\hline
\end{tabular}

Tabel 2. Kategori nilai pre test kemampuan berpikir siswa

\begin{tabular}{cccc}
\hline Interval Nilai & Kategori & Frekuensi & Presentase \\
\hline $91-100$ & Sangat tinggi & 5 & $14,71 \%$ \\
\hline $71-90$ & Tinggi & 4 & $11,76 \%$ \\
\hline $51-70$ & Sedang & 8 & $23,53 \%$ \\
\hline $41-50$ & Rendah & 10 & $29,41 \%$ \\
\hline $0-40$ & Sangat rendah & 7 & $20,59 \%$ \\
\hline & Jumlah & 34 & $100 \%$ \\
\hline
\end{tabular}

Dari tabel 2 kategori nilai pre test diketahui bahwa siswa sebagian besar mendapatakan nilai antara 41 sampai dengan 50 yaitu sebesar 10 siswa atau 29,41\% persen dari total keseluruhan sebelum diberi perlakuan. Siswa tersebut tergolong nilai sedang.

Berdasarkan hasil perhitungan dapat diketahui bahwa nilai tertinggi untuk post tes siswa atau hasil tes yang kedua kalinya adalah 100 dan nilai terendah adalah 42, sedangkan nilai rata-rata setelah diadakan pengujian yang kedua adalah 77,12 dengan nilai median sebesar 80,00 dan nilai modus sebesar 80,00 dengan nilai varians sebesar 301,74 dan simpangan baku adalah 17,37. Untuk mempermudah pembaca atas data hasil test diatas selanjutnya adalah pembuatan data statistik dan distribusi frekuensi untuk data yang telah dikelompokan adalah sebagai berikut:
Tabel 3. Data Statistik

\begin{tabular}{cc}
\hline Data Statistik & Pos Test \\
\hline Mean & 77,12 \\
\hline Median & 80,00 \\
\hline Modus & 80,00 \\
\hline Varians & 301,74 \\
\hline Simpangan baku & 17,37 \\
\hline Nilai maksimum & 100 \\
\hline
\end{tabular}


Tabel 4. Kategori nilai post test kemampuan berpikir siswa

\begin{tabular}{cccc}
\hline Interval Nilai & Kategori & Frekuensi & Presentase \\
\hline $91-100$ & Sangat tinggi & 7 & $20,59 \%$ \\
\hline $71-90$ & Tinggi & 16 & $47,06 \%$ \\
\hline $51-70$ & Sedang & 7 & $20,59 \%$ \\
\hline $41-50$ & Rendah & 4 & $11,76 \%$ \\
\hline $0-40$ & Sangat rendah & 0 & $100,00 \%$ \\
\hline
\end{tabular}

Dari tabel 4 Kategori nilai post test terhadap data yang telah di kelompokan diatas diketahui bahwa sebagian besar nilaipost test siswa atau setelah diberikan test yang kedua kalinya sebagian besar mendapatkan nilai 71 sampai dengan nilai 90 yaitu sebanyak 16 siswa atau 47,06\% dari total keseluruhan nilai setelah diberikan perlakuan atau nilai post test siswa tersebut tergolong memiliki nilai tinggi.

Kreatifitas merupakan kemampuan untuk menciptakan atau proses timbulnya sesuatu yang baru, baik berupa ide atau gagasan maupun karya nyata. Kreatifitas meliputi baik ciri-ciri aptitude seperti kelancaran, keluwesan dan keaslian dalam pemikiran.

Berdasarkan hasil perhitungan pretest dapat diketahui pada nilai kreatifitas awal siswa memiliki nilai tertinggi sebesar 95,00 dan nilai terendah senilai 75,00 sedangkan nilai rata-rata pre test sebesar 84,56 dengan nilai median sebesar 82,50 nilai modus sebesar 80,00 nilai varians sebesar 50,56 dan nilai simpangan baku sebesar 7,11. Selanjutnya untuk mempermudah pembaca atas data hasil test di atas langkah selanjutnya adalah pembuatan data satistik dan distribusi frekuensi untuk data-data yang telah dikelompokan adalah sebagai berikut:

Tabel 5. Data Statistik

\begin{tabular}{cc}
\hline Data Statistik & Nilai pre test \\
\hline Mean & 84,56 \\
\hline Median & 82,50 \\
\hline Modus & 80,00 \\
\hline Varians & 50,56 \\
\hline Simpangan baku & 7,11 \\
\hline Nilai maksimum & 95,00 \\
\hline Nilai minimum & 75,00 \\
\hline
\end{tabular}

Tabel 6. Kategori nilai pretest kemampuan kreatifitas siswa

\begin{tabular}{cccc}
\hline Interval Nilai & Kategori & Frekuensi & Presentase \\
\hline
\end{tabular}




\begin{tabular}{cccc}
\hline $91-100$ & Sangat tinggi & 8 & $23,53 \%$ \\
\hline $71-90$ & Tinggi & 26 & $76,47 \%$ \\
\hline $51-70$ & Sedang & 0 & 0 \\
\hline $41-50$ & Rendah & 0 & 0 \\
\hline $0-40$ & Sangat rendah & 0 & 0 \\
\hline & Jumlah & 34 & $100 \%$ \\
\hline
\end{tabular}

Dari tabel 6 Kategori nilai angket awal diketahui bahwa siswa sebagian besar mendapatakan nilai antara 71 sampai dengan 90 yaitu semua siswa atau persen dari total keseluruhan sebelum diberi perlakuan. Siswa tersebut tergolong nilai kreatif.

Untuk mengetahui nilai akhir setelah perlakuan atau setelah menerapkan metode lightening the learning climate peneliti menggunakan angket akhir. Berdasarkan hasil perhitungan diketahui bahwa nilai tertinggi kreatifitas siswa setelah memberikan perlakuan dan memberi kreatifitas adalah 100 dan nilai terendah adalah 75 Sedangkan nilai rata-rata setelah diadakan perlakuan yang kedua adalah 88,24, dengan nilai median sebesar 87,50 dan nilai modus sebesar 85,o dengan nilai varians sebesar 55,88 dan simpangan baku adalah 7,48. Untuk mempermudah pembaca atas data hasil test diatas selanjutnya adalah pembuatan data statistik dan distribusi frekuensi untuk data yang telah dikelompokan adalah sebagai berikut:
Tabel 7. Data Statistik

\begin{tabular}{cc}
\hline Daftar Statistik & Nilai Post Test Siswa \\
\hline Mean & 88,24 \\
\hline Median & 87,50 \\
\hline Modus & 85,00 \\
\hline Varians & 55,88 \\
\hline Simpangan Baku & 7,48 \\
\hline Nilai maksimum & 100,00 \\
\hline Nilai minimum & 75,00 \\
\hline
\end{tabular}

Tabel 8. Kategori nilai post test kemampuan kreatifitas siswa

\begin{tabular}{cccc}
\hline Interval Nilai & Kategori & Frekuensi & Presentase \\
\hline $91-100$ & Sangat tinggi & 9 & $26,47 \%$ \\
\hline $71-90$ & Tinggi & 25 & $73,53 \%$ \\
\hline $51-70$ & Sedang & 0 & 0 \\
\hline
\end{tabular}




\begin{tabular}{cccc}
\hline $41-50$ & Rendah & 0 & 0 \\
\hline $0-40$ & Sangat rendah & 0 & 0 \\
\hline & Jumlah & 34 & $100 \%$ \\
\hline
\end{tabular}

Dari tabel 8 Kategori nilai angket akhir terhadap data yang telah di kelompokan di atas diketahui bahwa sebagian besar nilai angket akhir setelah perlakuan adalah sebagian besar mendapatkan nilai 71 sampai dengan nilai 90 yaitu sebanyak 25 siswa atau $73,53 \%$ dari total keseluruhan nilai setelah diberikan perlakuan siswa tersebut tergolong memiliki nilai sangat kreatif.

Dari hasil analisis data di atas diperoleh perbedaan nilai statistik di mana nilai setelah perlakuan menerapkan metode lightening the learning climate atau nilai post test lebih meningkat.

Metode lightening the learning climate merupakan metode untuk meningkatkan kreatif siswa karena dalam metode ini siswa lebih aktif dan kreatif untuk mencari jawaban sendiri dan selanjutnya untuk dipresentasekan sehingga membuat mereka aktif dan mengingat kembali materi yang sudah dijelaskan.

\section{KESIMPULAN}

Berdasarkan hasil dan pembahasan penelitian dapat disimpulkan bahwa pada hasil penelitian ini nilai kemampuan berpikir siswa sebelum diberikan perlakuan metode lightening the learning climate adalah terdapat 4 siswa atau $11,76 \%$ siswa mendapatkan nilai kategori tinggi. Pada nilai kemampuan berpikir setelah perlakuan metode lightening the learning climate adalah terdapat 16 siswa atau $47,06 \%$ siswa mendapatkan nilai kategori tinggi. Pada nilai kreatifitas sebelum perlakuan metode lightening the learning climate adalah terdapat 26 siswa atau $76,47 \%$ siswa mendapatkan nilai kategori kreatif, dengan 23,53\% termasuk kategori sangat kreatif. Untuk nilai kreatifitas siswa sesudah perlakuan metode lightening the learning climate adalah $26,47 \%$ siswa mendapatkan nilai kategori sangat kreatif. Artinya, ada pengaruh positif terhadap kemampuan berpikir dan kreatifitas siswa dengan menggunakan metode lightening the learning climate.

Beberapa saran yang dapat dipertimbangkan dalam meningkat proses belajar siswa, yaitu guru diharapkan mempunyai pengetahuan yang cukup untuk memilih metode yang cocok dan sesuai dengan materi yang diajarkan sehingga dapat meningkatkan hasil belajar siswa serta diharapkan juga guru dapat merancang dan melaksankan suatu pembelajran yang dapat meningkat minat belajar serta kreatif siswa.

\section{REFERENSI}

Gravemeijer \& Cobb. 2006. "Design Research from a Learning Persperctive, dalam Educational Design Research. New York : Routledge

Liliasari, 2009. Inovasi Pembelajaran Sains Menuju Profesionalisme Guru. Program Studi Pendidikan IPA Sekolah Pascasarjana UPI Bandung. (Online), (http://file.upi.edu). Diakses 30 September 2018

Semiawan. 2009. Memupuk Bakat dan Kreatifitas Siswa Sekolah Menengah. Jakarta: Gramedia

Silberman. 2009. Aktif Learning 101 Strategi Pembelajaran Aktif. Diterjemahi Oleh Surjuli. Dkk. Yogyakarta: Pustaka Insan Mandani dan Yappendis

Soemanto. 2007. Psikologi Pendidikan (landasan kerja pemimpin pendidikan). Jakarta: Rineka Cipta

Supriadi, Dedi. 2000. Kreatifitas Kebudayaan dan Pengembangan Iptek. Bandung: Alfabeta

Suryabarata, Sumadi. 2001. Psikologi Pendidikan. Jakarta: Raja Grafindo 
Wastrisa. 2009. Aktif Learning 101 Strategi Pembelajaran Aktif. Diterjemahi Oleh Surjuli. Dkk. Yogyakarta: Pustaka Insan Mandani dan Yappendis

Yuliana, Eli. 2015. Pengembangan Soal Open Ended pada Pembelajaran Matematika untuk
Mengidentifikasi Kemampuan Berpikir Kreatif Siswa. Palembang: SNAPTIKA

Zaini. 2008. Strategi Pembelajaran Aktif. Yogyakarta: Pustaka Insan Mandiri 